\title{
Familial hypercholanemia
}

INSERM

\section{Source}

INSERM. (1999). Orphanet: an online rare disease and orphan drug data base. Familial hypercholanemia. ORPHA:238475

Familial hypercholanemia is a very rare genetic disorder characterized clinically by elevated serum bile acid concentrations, itching, and fat malabsorption reported in patients of Old Order Amish descent. 